\section{An analysis of budgetary goals impacting organizational performance}

Cheok MUI YEE, Edward WONG SEK KHIN,

Kamisah ISMAIL, Faculty of Business and Accountancy, University of Malaya, Malaysia, E-mail: edwardwong@um.edu.my

\section{Alustract}

This study proposes a conceptual review of how budgetary goals impact organizational performance. The aim of this study is to get a better understanding of the direct and indirect relationship between the organization's decision-making process and operational performances. Setting the budget particularly influences subordinates' budget goal levels and motivations (i.e., budget goal acceptance and budget goal commitment), which ultimately enhances the organization's performance. To test these relationships, data were collected using the three perspectives approach: budgetary goal, budgetary participation and budgetary evaluation. The study provided evidence that perception of fairness mediates the relation between the levels of budget participation and goal commitment, whereas goal commitment mediates the relation between fairness perceptions and performance. At the end of the article, there are some implications for SMEs industries and some suggestions for future studies.

Keywords: Budgetary goal, budgetary participation, budgetary evaluation, organization performance.

JEL Classification: M40; M41.
To cite this article:

Mui Yee, C., Wong Sek Khin, E. and Ismail, K. (2016),

An analysis of budgetary goals impacting organizational performance, Audit Financiar, vol. XIV, no. 5(137)/2016, pp. 551-563, DOI: 10.20869/AUDITF/2016/137/551

Permanent link to this document:

http://dx.doi.org/10.20869/AUDITF/2016/137/551 


\section{Introduction}

This paper is centred on the issue of budgetary goals. Thus, many organizations have to constantly strive to maximize their effectiveness and efficiency in the budgetary control process in order to maintain their competitive advantages. This is because having a proper budgetary control system allows companies to improve their managerial attitudes and performances within the organization and provide the organization with useful information to tackle the challenges faced (Ikävalko, Pihkala and Kraus, 2010). In view of this, this study will investigate whether budgetary goals have associations with organizational performances.

Thus, it is important to know how budgetary goals influence the organization's productive outcomes positively or negatively, especially when the givens concern ownership rights and formal authority who will express their opinions and perform their functions and responsibilities. However, industry practitioners may also offer insights, regardless if they are representing for-profit or not-for-profit organizations, all in order to reduce management-sourced errors when building budgeting goal activities (Yilmaz, Ozer and Gunluk, 2014).

According to El Luodi (1998), managers claimed that they can obtain the budgetary information easily; there is still a doubt on whether managers have a good understanding on the budgetary information and how the information has been put to good use or not in the decision-making process, as it will contribute to the success or failure of the companies. Moreover, Chong and Johnson (2007) found that task uncertainty is an important antecedent of budgetary participation. Employees who are low in analysability will tend to participate more in budgeting process when they require additional job-relevant information. However, their studies did not take into account other potential antecedents of budgetary participation such as perceived environmental uncertainty (Chong and Chong, 1997; Shields and Shields, 1998). Chong and Johnson (2007) also confirmed that participation in setting the budget influences subordinates' budget goal level and motivations (i.e., budget goal acceptance and budget goal commitment), which ultimately enhances their job performance. Thus, the level of awareness on the importance of understanding the role of budgetary goals in determining the performance of the budgeting process so as to achieve effective budgetary control must be arisen.

The research objectives are as follows:

i. To examine the characteristics of budgetary goals;

ii. To examine the extent to which perceived environmental uncertainty (PEU) will influence budgetary participation;

iii. To examine the extent to which budget characteristics, namely participation, feedback and evaluation, will influence perception of fairness;

iv. To examine the extent to which perception of fairness will influence goal acceptance;

v. To examine the extent to which perception of fairness will influence goal commitment;

vi. To examine the extent to which goal acceptance will influence budgetary performance;

vii. To examine the extent to which goal commitment will influence budgetary performance.

Based on the objectives identified above, this section lays out the questions developed in achieving the objectives:

i. What are the characteristics of budgetary goals?

ii. How significant are the relationships between perceived environmental uncertainty (PEU) and budgetary participation?

iii. How significant are the relationships between budget characteristics, namely participation, budgetary feedback and evaluation, and perception of fairness?

iv. How do perceptions of fairness influence the acceptance of goals?

v. How do perceptions of fairness influence the commitment of goals?

vi. How individuals' acceptances of goals contribute to the influence of budgetary performance?

vii. How individuals' commitment to goals contribute to budgetary performance?

In addition to the introduction, the first section reviews the relevant literature regarding organization performance and budgetary goals. The second section describes the research methodology and outlines the analysis of the data. The third section presents the empirical results, and the fourth - the conclusions. 


\section{Literature review}

\section{Organisation performance and economic growth}

Today, firms and organizations like SMEs are to constantly strive to maximize their effectiveness and efficiency in the budgetary controlling process in order to maintain their competitive advantages. It is because having a proper budgetary control system allows companies to improve their managerial attitude and performance of the organisations and provide organisations with useful information (Nasiha, Nadzri and Najib, 2013). The development of Small and Medium Enterprises (SMEs) is the major driving force in the economic growth of developing countries, which play a significant role in the contribution of balance of trade in the macro-context (Hamilton and Harper, 1994). Particularly, in Malaysia, SMEs are made up of $99 \%$ businesses of industrial sectors which constitute $35 \%$ of Gross Domestic Product of the country and $20 \%$ of the overall exports (Zeti, 2010).

Many SMEs do not realize the importance of having proper budgetary goals that can accurately reflect their financial position. Camino and Cardone (1999) explained that many SMEs fail to prepare detail working papers attached with budget plan and projected cash flow statement when they apply for loans. Thus, SMEs face difficulties in obtaining funds from financial institutions and government.

Particularly, they fail to understand the importance of using budgetary reports for decision-making of resource allocation to reduce uncertainty in decision-making (Shahwan and Al-Ain, 2008). Shahwan and Al-Ain (2008) indicated that most small companies either find the budgetary information not useful or they lack proper budgetary control in their system design. They even pointed out that only a very small percentage of analysed companies prepare budgetary information for the use of decision-making and long term strategy planning. Thus, such inefficiency or poor managerial ability may negatively affect the growth of an organisation (Barker, 2003). As a result, the management has to improve its effective and efficiency of business activities. That is why Mitchell et al. (2000) stress the importance of applying budgetary information for problem-solving and decision-making in order to excel organization performance.

\section{Budgetary goal characteristics}

A budget is an accounting tool that sets the costs and revenues goals for responsibility centres within an organization and also a measurement tool for control, coordination, communication, performance and motivation. Thus, dissemination of knowledge about budgetary goals should be carefully planned by upper management and understood by members of organizations so that they can implement an effective budget. In other words, proper use of budgets may result in a useful managerial tool. However, on the reverse side, improperly application of a budget can lead to dysfunctional behaviour and raise negative attitudes within an organization. By gaining an understanding of the budgetary goals characteristics, these may lead to an accurate budget, directly and through organizational commitment, and therefore to improved performance (Nouri and Parker, 1998). The concept of how budget goals are determined can be traced back to the budgeting style of management, which includes the participation of management, the amounts of feedback received within the organization, and the use of budgets for performance evaluation (Kenis, 1979).

\section{Budgetary participation}

Budgetary participation is referred to as the extent to which those concerned participate in preparing the budgets and influence the budget goals of their responsibility centres (Kenis, 1979). Active participation in the setting of budgetary goals encourages employees to have clearly defined goals in mind and be willing to accept these goals as part of their responsibilities, as well as to strive toward their accomplishment.

\section{Budgetary feedback}

Employees need to be informed and provide feedback as to whether budget goals have been achieved or not, as it is an important motivational variable (Kenis, 1979). If they are kept in the dark and do not know the results of their efforts, they have a sense of failure, and there is no sense of their successes for achieving higher goals or, on the other hand, accepting new goals for improving their future performances.

\section{Budgetary evaluation}

Budgetary evaluation is referred to as the extent to which budget variances are traced back to individual 
departmental heads and used in evaluating their performance (Kenis, 1979). The ways in which budgets are used in performance evaluation tend to influence behaviours, attitudes, and the performance of employees. For instance, a punitive approach may lead to lower motivation and negative attitudes, whereas a supportive approach may result in positive attitudes and behaviours.

\section{Budgetary performance}

Budgetary performance is widely adopted to examine how well organizations perform in their implementation of budgets and how effective each reason-to-budget is perceived to be by all within an organization (Hansen and Stede, 2004). The performance of a budget is also associated with a relatively different set of budgeting characteristics, such as choice of target difficulty, amount of participation in the budgeting process, and amount of emphasis on meeting budget targets.

Hansen and Stede (2004) concluded that "the reason-tobudget performance on operational planning, performance evaluation, communication of goals, and strategy formation is positively associated with overall budget satisfaction". However, some studies (Tsui, 2001; Jermias and Setiawan, 2008) found that performance outcome may not be outlined when it is being operated for multiple purposes, particularly in planning and evaluations. They believe that the evaluation of the performance of a budget is different depending on the purposes of the budgetary control systems of organizations (Mizutani and Nakamura, 2012).

\section{Research methodology}

In developing the research framework, the authors proposed to incorporate a model to conceptualize the relationship between budgetary goal characteristics and budgetary performance. According to the conceptual model, the link between characteristics of budgetary goals and performance is mediated by perception of fairness, goal acceptance and goal commitment. The model developed to empirically test such relationship is depicted in Figure 1, which includes the conceptual model's justification, description, and explanation. The presumed relationships with other constructs are presented below. The model, as it can be noticed, is meant to illustrate the links between the constructs. The model comprises six main elements: budgetary participation, budgetary feedback, budgetary evaluation, perception of fairness, goal acceptance and goal commitment.

\section{Figure 1: Research model and proposed hypotheses}

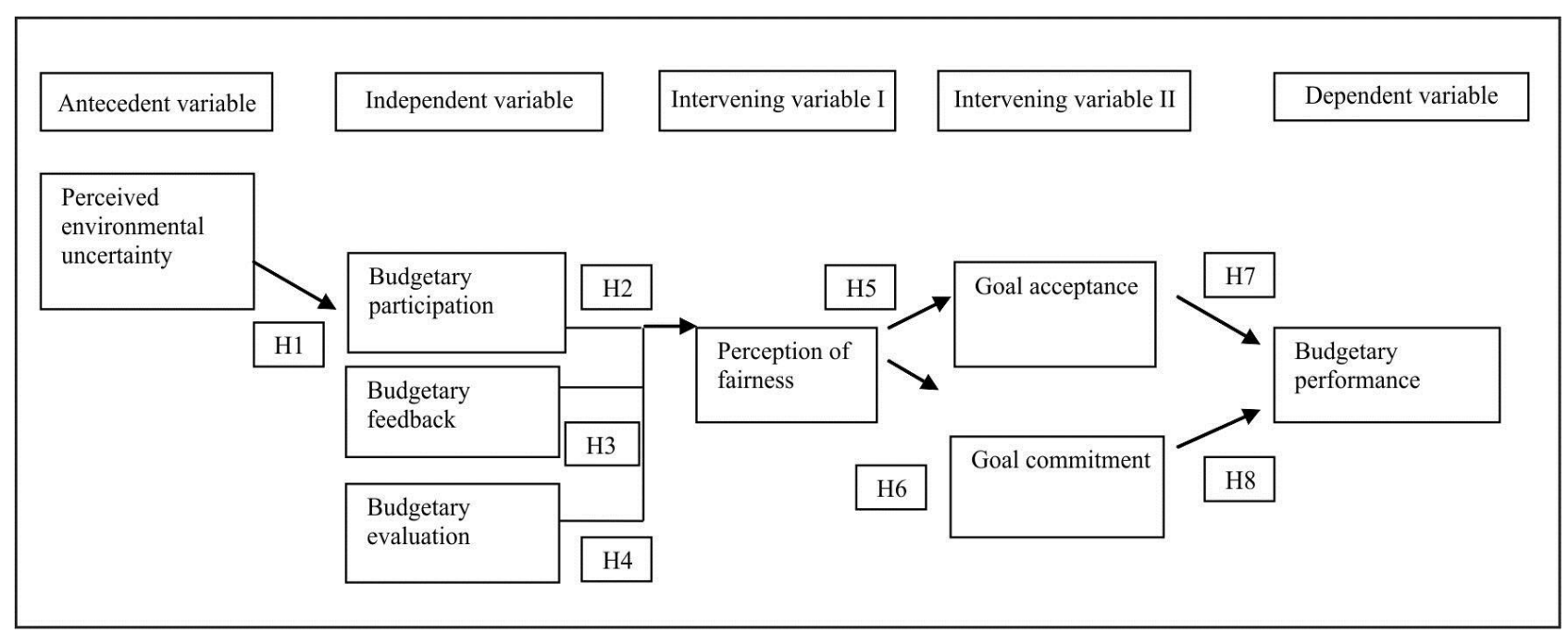

Source: Author's compilation, 2016 
The basic purpose of this research is to examine whether the three perspectives of independent variables such as budgetary goal, budgetary participation and budgetary evaluation influence the performance of SMEs. The targeted samples were executives, managers, or managing director of SMEs. A questionnaire was designed based on discussion with SMEs' managing directors. Based on the pre-test results, several items on the questionnaire were revised. The final version of the questionnaire was sent to the respondents using the survey method. The self-administering questionnaires were distributed to a convenience sample of 60 SMEs. The study involved the adoption of a non-probability sampling method. Statistical Package for Social Science (SPSS) was used to analyse the survey data. Primary data and secondary data were used.

\section{The link between Perceived Environmental Uncertainty (PEU) and budgetary participation}

Based on contingency theory, a contextual variable such as environmental uncertainty is a co-relational antecedent of participative budgeting (Birnberg et al., 1990). Gul and Chia (1994) suggested that when PEU is low, management is able to make relatively accurate predictions about the market. However, when PEU is high, management may require additional information to cope with the complexity of the environment. Besides, subordinates can obtain additional jobrelevant information through their budgetary participation (Campbell and Gingrich, 1986; Mia, 1987; Shields and Shields, 1998). Thus, it suggests that employees will be keener to participate in information seeking for task completion during periods of high uncertainty. Hence, it is postulated that perceived environmental uncertainty is expected to be positively associated with budgetary participation. Hypothesis 1 tests for this positive association:

H1: There is a positive significant relationship between Perceived Environmental Uncertainty (namely, state uncertainty, effect uncertainty and response uncertainty) and budgetary participation.

\section{The link between budgetary participation and perception of fairness}

Based on fairness theory, the concept of distributive fairness stresses that people need to feel that they have received their fair share of available benefits, i.e., the fair outcome of a discussion or other decision-making process. This is because people put a higher value on their own contributions than they value the identical contributions of others (Ting and Yu, 2010). People are highly influenced by social comparisons of information even in performance situations where objective information is available (Klein, 1977). Thus, it is suggested that, by actively participating in budgetary process, employees perceive that they have a greater opportunity of influencing a 'fair' allocation of resources. Hence, this postulates that distributive fairness should increase at the same time as the opportunities to gain greater active participation in the process of budget allocations increase.

Hypothesis 2a tests for this positive association:

H2a: Budget participation and perception of distributive fairness among budgeteres (those involved with a given budget) are positively related.

On the other hand, the concept of procedural fairness stresses that people are perceived to value the fairness of procedures or processes that are used to arrive at the desired outcomes. People who believe that they have been treated in a procedurally fair manner are more likely to conclude that the resulting outcome is substantively fair. Also, people are more likely to judge a process as fair if they are given the opportunity to express their opinions or suggestions. When employees are actively involved in the budgetary process, they can express their stand clearly to the decision-makers and, in return, the employees can have a better understanding of how budget distributions are determined. Hence, this postulates that employees can gain control over the budgetary process when they participate actively. Hypothesis $2 b$ tests for this positive association:

H2b: Budget participation and perception of procedural fairness among budgeters are positively related.

\section{The link between budgetary feedback and perception of fairness}

In the concept of distributive fairness, a person's perception of 'equitable outcome' is inevitably affected by self-interest or an egocentric bias. When asked to 
determine what amount they should be paid for accomplishing a particular task, people expect to be paid substantially more for their own work than they are willing to pay someone else.

In the concept of perception of procedural fairness, people who believe that they have been treated in a procedurally fair manner are more likely to conclude that the resulting outcome is substantively fair. They care about the consideration that they received from the decision-maker. In other words, in a process that feels fair, people need to receive assurance that decisionmakers have listened to them, understood, and cared about what they had to say.

Similarly, the effectiveness of feedback, or the extent to which feedback serves motivational and regulatory purposes, can depend on an employee's perception of feedback (Tata, 2002). They will also constantly evaluate the adequacy of outcomes by comparing the feedback received on these outcomes to the related goals assigned by the organizations (Wofford and Goodwin, 1990). When an unexpected discrepancy is indicated by the feedback, employees will either take it positively or negatively. On the bright side, employees may be motivated to change their work behaviour; on the other hand, if employees perceive the feedback to be inaccurate or useless and are dissatisfied with this result, they will tend to ignore the comments and not use the advice they receive (Jawahar, 2010).

Although previous research has not examined the direct relationship between budgetary feedback and the perception of fairness, a few studies have presented mixed results in examining how critical performance reviews influence appraisal reactions (Jawahar, 2010). Thus, it is suggested that when employees receive positive or (negative) feedback from reviewers, they may (or may not) support the advice of the reviewer if there is (or there is not) support for it in their own evaluations. In view of such mixed findings, a non-directional hypothesis is:

H3: Budgetary feedback relates to perception of fairness (namely, distributive fairness and procedural fairness).

\section{The link between budgetary evaluation and perception of fairness}

In the concept of distributive fairness, a person's perceptions of outcome fairness are influenced by how they consider they were treated during a dispute resolution or in the decision-making process. If they perceive themselves as treated in a procedurally fair manner, they are more likely to judge the outcome of that process as fair.

In the concept of perception of procedural fairness, people who believe that they are treated fairly in a decision-making process are more likely to comply with the outcome. This effect will occur even if the outcomes are not personally favourable.

When an evaluation is used effectively, organizational members will have the same frame of reference in respect to performance information, which allows everyone in the organizations to interpret the information in the same or similar manner (Waal, 2004). On the other hand, if the accuracy and legitimacy of the result of the evaluation are weak, an inconsistent and incoherent message will be sent to employees that possibly diminish the decision's pay-off to certain employees and cause some psychological discomfort (Hanberger, 2011). Thus, the 'satisfaction' of employees has a foundation based upon whether the assessment of procedures is fair or not (Heuer, Penrod and Kattan, 2007).

Although there are no studies done in examining this fairness theory relationship, it is assumed that people who are involved in the evaluation process are concerned with maximizing their self-interests (Heuer, Penrod and Kattan, 2007). When employees feel that they are evaluated unfairly, psychological dysfunction may occur, and it is suggested that for an evaluation to be effective, it should be conducted in accordance to the perceived fairness of the employees affected. Hypothesis 4 tests for this negative association:

H4: Budgetary evaluation and perception of fairness, namely, procedural fairness and distributive fairness are negatively related.

\section{The link between perception of fairness and goal acceptance}

Based on goal setting theory, goal acceptance is influenced greatly by the degree of perceived locus of goal setting. It means that people are more likely to accept the goal when it is perceived to be under their control than when it is perceived as externally imposed (Erez and Kanfer, 1983). This is because such controlling power satisfies people's need to feel a sense 
of mastery and personal competence. Any threat to their sense of control results in reactance or non-compliance. Such explanations can be coined into the theory of fairness as well. In terms of distributive fairness, people are inevitably affected by self-interest or an 'egocentric bias' when they aim to achieve an 'equitable income'. In addition, in procedural fairness, people will consider accepting the proposal when they receive assurance that decision-makers have cared about what they had to say. Research from judicial decision-making has found that the perception of justice is positively related to the acceptance of the decision outcome (Renn, 1998). Thus, it is suggested that employees who perceive themselves as being treated fairly tend to demonstrate greater willingness to accept the goals assigned. Thus, it is hypothesized that:

\section{H5: Perceptions of fairness (namely, procedural fairness and distributive fairness) are positively related to acceptance of goals.}

\section{The link between perception of fairness and goal commitment}

In the concept of distributive fairness, when people feel that they are treated in a fair manner, they are more likely to judge the outcome of that process as fair. These people will gradually build a strong attachment with the decision-makers or institutions, whereby they will be treated as friends. Such relationship will become beneficial in the end and people will be able to build high individual aspirations and commitment.

In the concept of perception of procedural fairness, people are more likely to comply with the outcome of the procedure when they believe that they are treated fairly in a decision-making process. Such perception affects employees' respect and loyalty accorded to those decision-makers and the institution that sponsors the decision-making process, as they value a process that accords them dignity and respect (Hobson, Mellon and Stevens, 2011).

Such explanations of perception of fairness can be applied to the goal-setting theory as well. When employees believe that the outcome of the decision-making process is in favour of their personal interests, they will be more likely to commit to the goals, provided that the decision is based upon a fair process. On the other hand, employees perceive a greater chance of success when the distribution of budget resources is adequate. Although the relationship between perception of fairness and goal commitment has not been examined extensively, the application of justice or fairness theory to goal commitment issue suggests a positive relationship (Wentzel, 2002). Thus, it is hypothesized that:

\section{H6: Perception of fairness (namely, procedural fairness and distributive fairness) is positively related to commitment of goals.}

\section{The link between goal acceptance and budgetary performance}

Based on goal setting theory, goals will only be accepted by people who are inspired by their own self-set goals, not by the organizational goals. When such goals are accepted, task performance will be improved as well, both for specific and hard goals. It is because the establishment of goals is derived from an individual's intention of reaching the goals (Erez and Kanfer, 1983). Although no previous study has examined the direct relationship between goal acceptance and budgetary performance from the perspective of management accounting, it is assumed that an individual's goals must be accomplished before organizations can attain their desired results in terms of budgetary performance. Thus, it is suggested that when employees are willing to accept organizational goals as their own self-set goals, the desired performance will be improved. It is hypothesized that:

\section{H7: Acceptance of goals is positively related to budgetary performance.}

\section{The link between goal commitment and budgetary performance}

Commitment to budgetary goals is particularly important when performance of organizations depends largely on the productivity of employees and on whether they can or cannot achieve company objectives. Goal setting theory assumes that individuals will be committed when they are assigned with goals. It is evident that employees improve their performance when they accept and commit to attain a particular goal (Wentzel, 2002). On the other hand, if employees are not committed to the goals, there will not only be a low productivity level, but also an employees' increased resistance to change (Locke and Latham, 1990). Thus, it is suggested that when employees are committed to budgetary goals, performance will be improved for the organizations. It is hypothesized that: 
H8: Commitment of goals and budgetary performance are positively related.

\section{Results and discussions}

\section{Normality Test}

According to Gosselin (2005), the normality of all the variables was tested by assessing the skewness and kurtosis values. When data is normally distributed, the value of skewness and kurtosis are zero, as values outside the range of +2 or -2 demonstrate considerable degrees of non-normality (Gosselin, 2005). In this study most of skewness and kurtosis values for all the variables are within the range of +2 or -2 (refer to Table 1 ).

\begin{tabular}{|c|c|c|c|c|}
\hline Measurements & Mean & Standard deviation & Skewness & Kurtosis \\
\hline Budgetary goal perspective & 1.68 & 0.49 & 0.03 & 0.24 \\
\hline Budgetary participation perspective & 2.08 & 0.79 & 0.37 & -0.21 \\
\hline Budgetary evaluation perspective & 2.19 & 0.69 & 0.06 & -0.44 \\
\hline Budgetary performance & 2.20 & 0.76 & 0.25 & -0.55 \\
\hline Organisation performance & 1.97 & 0.39 & 0.39 & 1.61 \\
\hline
\end{tabular}

Source: Author's compilation, 2016

\section{Reliability Test}

According to Handler (1989), using Cronbach's coefficient alpha allows to measure the internal consistency of scale (as its value ranges from 0 to 1 ). Reliability testing on all measures was necessary. Table 2 summarizes the Cronbach's coefficient alpha for each measure. A scale is reliable if the coefficient value is more than 0.600 (Handler, 1989). All the measures in this study are reliable as this scale has the highest coefficient alpha value of 0.87 . The measure having reliability coefficients lower than 0.700 was normative commitment.

\begin{tabular}{|l|c|c|}
\hline \multicolumn{1}{|c|}{ Table 2. Reliability of measures } \\
\hline No Cronbach's & Measure of items & Coefficient alpha \\
\hline Budgetary goal perspective & 3 & 0.73 \\
\hline Budgetary participation perspective & 5 & 0.79 \\
\hline Budgetary evaluation perspective & 5 & 0.75 \\
\hline Budgetary performance & 8 & 0.77 \\
\hline
\end{tabular}

Source: Author's compilation, 2016

According to Sidin and Zawawi (2002) the Pearson correlation coefficient indicates the strength of relationship between the variables. Hence, a correlation coefficient between 0.10 and 0.29 indicates a small correlation, while a coefficient between 0.30 and 0.49 indicates a medium correlation and a coefficient between 0.50 and 1.0 indicates a large correlation (Sidin and Zawawi, 2002). 
Table 3. Multiple regression analysis of model $\mathrm{HI}, \mathrm{H2}, \mathrm{H3}, \mathrm{H4}, \mathrm{H} 5, \mathrm{H6}, \mathrm{H7}, \mathrm{H8}$

\begin{tabular}{|c|c|c|c|c|c|c|}
\hline \multicolumn{9}{|c|}{ Model summary } & \multicolumn{2}{c|}{ ANOVA } \\
\hline Model & R & R-square & Adjusted R-square & Std. error of the estimate & F & Sig \\
\hline H1 & $0.82 \mathrm{a}$ & 0.67 & 0.66 & 2.45 & 59.17 & $0.00 \mathrm{a}$ \\
\hline H2 & $0.65 \mathrm{a}$ & 0.42 & 0.40 & 7.44 & 21.24 & $0.00 \mathrm{a}$ \\
\hline H3 & $0.37 \mathrm{a}$ & 0.13 & 0.10 & 9.12 & 4.47 & $0.04 \mathrm{a}$ \\
\hline H4 & $0.38 \mathrm{a}$ & 0.15 & 0.12 & 9.03 & 5.11 & $0.03 \mathrm{a}$ \\
\hline H5 & $0.72 \mathrm{a}$ & 0.52 & 0.50 & 2.75 & 55.25 & $0.00 \mathrm{a}$ \\
\hline H6 & $0.55 \mathrm{a}$ & 0.30 & 0.30 & 6.43 & 18.24 & $0.00 \mathrm{a}$ \\
\hline H7 & $0.47 \mathrm{a}$ & 0.23 & 0.20 & 8.16 & 5.47 & $0.04 \mathrm{a}$ \\
\hline H8 & $0.48 \mathrm{a}$ & 0.23 & 0.20 & 8.05 & 5.61 & $0.03 \mathrm{a}$ \\
\hline
\end{tabular}

Source: Author's compilation, 2016

H1: There is a positive significant relationship between perceived uncertainty (PEU) (namely, state uncertainty, effect uncertainty and response uncertainty) and budgetary participation.

Supported because $r=0.82, p<0.00$ and $66 \%$ for adjusted $r$-square. Also the analysis showed the significance effect as indicated by $F$ value from the ANOVA table with $F=59.17, p=0.000<.05$.

H2a: Budget participation and perception of distributive fairness among budgeters are positively related.

Supported because $r=0.65, p<0.00$ and $40 \%$ for adjusted r-square. Also the analysis showed the significance effect as indicated by $F$ value from the ANOVA table with $F=21.24, p=0.000<.05$.

H3: Budgetary feedback is related to perception of fairness (namely, distributive fairness and procedural fairness).

Supported because $r=0.37, p<0.00$ and $13 \%$ for adjusted r-square. Also the analysis showed the significance effect as indicated by $F$ value from the ANOVA table with $\mathrm{F}=4.47, \mathrm{p}=0.000<.05$.

H4: Budgetary evaluation and perception of fairness, namely, procedural fairness and distributive fairness, are negatively related.

Supported because $r=0.38, p<0.00$ and $15 \%$ for adjusted r-square. Also the analysis showed the significance effect as indicated by $F$ value from the ANOVA table with $\mathrm{F}=5.11, \mathrm{p}=0.000<.05$.
H5: Perception of fairness (namely, procedural fairness and distributive fairness) is positively related to acceptance of goals.

Supported because $r=0.72, p<0.00$ and $52 \%$ for adjusted $r$-square. Also the analysis showed the significance effect as indicated by $F$ value from the ANOVA table with $F=55.25, p=0.000<.05$.

H6: Perception of fairness (namely, procedural fairness and distributive fairness) is positively related to commitment of goals.

Supported because $r=0.55, p<0.00$ and $30 \%$ for adjusted $r$-square. Also the analysis showed the significance effect as indicated by $F$ value from the ANOVA table with $F=18.24, p=0.000<.05$.

H7: Acceptance of goals is positively related to budgetary performance.

Supported because $r=0.47, p<0.00$ and $23 \%$ for adjusted r-square. Also the analysis showed the significance effect as indicated by $F$ value from the ANOVA table with $\mathrm{F}=5.47, \mathrm{p}=0.000<.05$.

H8: Commitment of goals and budgetary performance are positively related.

Supported because $r=0.48, p<0.00$ and $23 \%$ for adjusted $r$-square. Also the analysis showed the significance effect as indicated by $F$ value from the ANOVA table with $F=5.61, p=0.000<.05$. 


\section{Discussions}

Many organizations are unaware of the importance of having proper budgetary goals that can accurately reflect their financial position. Camino and Cardone (1999) explain that many organizations fail to prepare detailed working papers attached to the budget plan and projected cash flow statement, when they apply for loans. Thus, organizations face difficulties in obtaining funds from financial institutions and government (Yunos, Zubaidah and Smith, 2012).

In particular, they fail to understand the importance of using budgetary reports for decision-making and resource allocation, which reduce uncertainty in their decision-making (Shahwan and Al-Ain, 2008). Shahwan and Al-Ain (2008) indicate that most small companies either find the budgetary information not useful or they are lacking proper budgetary controls in their system design. They even point out that only a very small percentage of companies prepare such information for the use of decision-making and for long term strategy planning. Thus, such inefficiency or poor managerial ability negatively affects the growth of an organization (Barker, 2003). As a result, management has to improve its effectiveness and efficiency of business activities.

Although many managers in this survey claimed that they can obtain the budgetary information easily, there is still doubt on whether managers have a good understanding of the available budgetary information and whether the information has (or has not been) well used in decision-making. This data contributes to the success or failure of the companies (El Luodi, 1998). Thus, the level of awareness of understanding the importance of budgetary goals in determining the firm's overall performance, lays in the successful use of the budgeting process.

\section{Conclusions}

The contributions from this study are discussed from theoretical, methodology and practical perspectives. From a theoretical perspective, this study contributes to the development of the existing knowledge in three ways.

Firstly, the study found that task uncertainty is an important antecedent of budgetary participation. Employees who are low in budgetary analysis skills will tend to participate more in the budgeting process when they require additional job-relevant information.

Secondly, participation in setting the budget influences subordinates' budget goal levels and motivations (i.e., budget goal acceptance and budget goal commitment), which ultimately enhances their job performance. The study provided evidence that perception of fairness mediates the relation between levels of budget participation and goal commitment, whereas goal commitment mediates the relation between fairness perceptions and performance.

Thirdly, participation affects performance through its effects upon goal acceptance, and therefore performance also increases. Participation in goal setting enhances goal acceptance, especially when presenting individuals with goals that they initially rejected because they perceived these goals as being unreasonable or too difficult.

Lastly, many organizations should strive to maximize effectiveness and efficiency in the budgetary controlling process in order to maintain their competitive advantages. This is because having a proper budgetary control system allows companies to improve their managerial attitude and performance and provide these organizations with useful information to tackle their daily financial challenges.

\section{REFERENCES}

1. Barker, R. (2003), The revolution ahead in financial reporting: Reporting financial performance, Balance Sheet, vol. 11, no. 4, pp. 19-23, DOI: http://dx.doi.org/10.1108/09657960310502502.

2. Birnberg, J.C. Shields, M.D. and Young, S.M. (1990), The case for multiple methods in empirical management accounting research: With an illustration from budget setting, Journal of
Management Accounting Research, vol. 2, no. 1, pp. 33-66.

3. Camino, D. and Cardone, C. (1999), The valuation and cost of credit issuance schemes for SMEs: The role of the loan guarantee association, International Small Business Journal, vol. 17, no. 44, pp. 13-31, DOI: http://dx.doi.org/10.1177/0266242699174001. 
4. Campbell, D.J. and Gingrich, K.F. (1986), The interactive effects of task complexity and participation on task performance: A field experiment, Organisational behaviour and Human Decision Processes, vol. 38, no. 2, pp. 162-180, DOI: http://dx.doi.org/10.1016/07495978(86)90014-2.

5. Chong, V.K. and Chong, K.M. (1997), Strategic choices, environmental uncertainty and SBU performance: A note on the intervening role of Management Accounting Systems, Accounting and Business Research, vol. 27, no. 4, pp. 268276, DOI: http://dx.doi.org/10.1080/ 00014788.1997.9729553.

6. Chong, V.K. and Johnson, D.M. (2007), Testing a model of antecedents and consequences of budgetary participation on job performance, Accounting and Business Research, vol. 31, no. 1, pp. 3-19, DOI: http://dx.doi.org/10.1080/ 00014788.2007.9730055.

7. El Luodi, M. (1998), The relationship among organization structure, information technology and information processing in small Canadian firms, Canadian Journal of Administrative Sciences, vol. 15, no. 2, pp. 180-199, DOI: http://dx.doi.org/10.1111/j.19364490.1998.tb00161.x.

8. Erez, M. and Kanfer, F.H. (1983), The role of goal acceptance in goal setting and task performance, The Academy of Management Review, vol. 8, no. 3, pp. 454-463.

9. Gosselin, M. (2005), An empirical study of performance measurement in manufacturing firms, International Journal of Productivity and Performance Management, vol. 54, no. 5-6, pp. 419-437.

10. Gul, F.A. and Chia, Y.M. (1994), The effects of management accounting systems, perceived environmental uncertainty and decentralization on managerial performance: A test of three-way interaction, Accounting, Organisations and Society, vol. 19, no. 4-5, pp. 413-426, DOl: http://dx.doi.org/10.1016/0361-3682(94)90005-1.

11. Hamilton, R.T. and Harper, D.A. (1994), The entrepreneur in theory and practice, Journal of Economic Studies, vol. 21, no. 6, pp. 3-18, DOI: http://dx.doi.org/10.1108/01443589410071391.
12. Hanberger, A. (2011), The real functions of evaluation and response systems, Evaluation, vol. 17, no. 4, pp. 327-349, DOl: http://dx.doi.org/10.1177/1356389011421697.

13. Handler, W.C. (1989), Methodological issues and considerations in studying family businesses.

Family Business Review, vol. 2, no. 3, pp. 257276, DOI: http://dx.doi.org/10.1111/j.17416248.1989.00257.x.

14. Hansen, S.C. and Stede, W.A. (2004), Multiple facets of budgeting: An exploratory analysis, Management Accounting Research, vol. 15, no. 4, pp. 415-439, DOI: http://dx.doi.org/10.1016/j.mar.2004.08.001.

15. Heuer, L., Penrod, S. and Kattan, A. (2007), The role of societal benefits and fairness concerns among decision makers and decision recipients, Law Human Behaviour, vol. 31, no. 6, pp. 573630, DOl: http://dx.doi.org/10.1007/s10979-0069084-2.

16. Hobson, J.L., Mellon, M.J. and Stevens, D.E. (2011), Determinants of Moral Judgments Regarding Budgetary Slack: An Experimental Examination of Pay Scheme and Personal Values, Behavioral Research in Accounting, vol. 23, no. 1, pp. 87-107, DOI: http://dx.doi.org/10.2308/bria.2011.23.1.87.

17. Ikävalko, M., Pihkala, T. and Kraus, S. (2010), The Role of Owner-Managers' Psychological Ownership in SME Strategic Behaviour, Journal of Small Business \& Entrepreneurship, vol. 23, no. 3, pp. 461-479, DOI: http://dx.doi.org/ 10.1080/08276331.2010.10593496.

18. Jawahar, I.M. (2010), The mediating role of appraisal feedback reactions on the relationship between rater feedback-related behaviour and rate performance, Group and Organization Management, vol. 35, no. 4, pp. 494-526, DOI: http://dx.doi.org/10.1177/1059601110378294.

19. Jermias, J. and Setiawan, T. (2008), The moderating effects of hierarchy and control systems on the relationship between budgetary participation and performance, The International Journal of Accounting, vol. 43, no. 3, pp. 268292, DOI: http://dx.doi.org/10.1016/j. intacc.2008.06.009. 
20. Kenis, I. (1979), Effects of budgetary goal characteristics on managerial attitudes and performance, The Accounting Review, vol. 10, no. 4, pp. 707-721.

21. Klein, W.M. (1997), Objective standards are not enough: Affective, self-evaluative, and behavioural responses to social comparison information, Journal of Personality and Social Psychology, vol. 72, no. 4, pp. 763-774, DOI: http://dx.doi.org/10.1037/0022-3514.72.4.763.

22. Locke, E.A. and Latham, G.P. (1990), A theory of goal setting and task performance, Eagewood Cliffs, New Jersey: Prentice Hall.

23. Mia, K. (1987), Participation in budgetary decision-making, task difficulty, locus of control and employee behaviour: An empirical study, Decision Science, vol. 18, no. 4, pp. 547-561, DOI: http://dx.doi.org/10.1111/j.15405915.1987.tb01546.x.

24. Mitchell, R., Smith, B., Seawright, K. and Morse, E. (2000), Cross-cultural cognitions and the venture creation decision, Academy of Management Journal, vol. 43, no. 5, pp. 974993, DOl: http://dx.doi.org/10.2307/1556422.

25. Mizutani, F. and Nakamura, E. (2012), Managerial incentive, organizational slack, and performance: Empirical analysis of Japanese firms' behavior, Journal of Management \& Governance, vol. 18, no. 1, pp. 245-284, DOl: http://dx.doi.org/10.1007/s10997-012-9226-5.

26. Nasiha, N., Nadzri, M. and Najib, M. (2013), Implementation public private partnership on participation in Malaysia: A review on participation of local government and private sectors in land development, Proceedings of the Global Conference on Business, Economics and Social Sciences (GBSR 2013).

27. Nouri, H. and Parker, R. (1998), The relationship between budget participation and job performance: The roles of budget accuracy and organisational commitment, Accounting, Organisations and Society, vol. 25, no. 5-6, pp. 5-6.

28. Renn, R.W. (1998), Participant's effect on task performance: Mediating roles of goal acceptance and procedural justice, Journal of Business Research, vol. 41, pp. 115-125, DOl: http://dx. doi.org/10.1016/S0148-2963(97)00020-9.
29. Sahwan, Y. and Al-Ain (2008), Qualitative characteristics of financial reporting: A historical perspective, Journal of Applied Accounting Research, vol. 9, no. 3, pp. 192-202, DOI: http://dx.doi.org/10.1108/09675420810919748.

30. Shields, J.F. and Shields, M.D. (1998), Antecedents of budgetary participation, Accounting, Organizations and Society, vol. 23, no. 1, pp. 49-76, DOI: http://dx.doi.org/10. 1016/S0361-3682(97)00014-7.

31. Sidin, S. and Zawawi, D. (2002), The relationship between organizational commitment and job performance amongst executives in Malaysia, Proceedings of the Asia Pacific Economics and Business Conference, pp. 937-945.

32. Tata, J. (2002), The influence of managerial accounts on employees' reactions to negative feedback, Group and Organisation Management, vol. 27, no. 4, pp. 480-503, DOl: http://dx.doi.org/10.1177/1059601102238358.

33. Ting, C.Y and Yu, T. K. (2010), Modelling patient perceptions of service recovery: The effects of perceived fairness on health center repatronage, Social Behaviour and Personality, vol. 38, no. 3, pp. 395-404.

34. Tsui, J. (2001), The impact of culture on the relationship between budgetary participation, management accounting systems, and managerial performance: An analysis of Chinese and Western managers, The International Journal of Accounting, vol. 36, no. 2, pp. 125146, DOI: http://dx.doi.org/10.1016/s00207063(01)00101-7.

35. Waal, A.A. (2004), Stimulating performancedriven behavior to obtain better results, International Journal of Productivity and Performance Management, vol. 53, no. 4, pp. 301-306, DOl: http://dx.doi.org/ 10.1108/17410400410533890.

36. Wentzel, K. (2002), The influence of fairness perceptions and goal commitment on managers' performance in a budget setting, Behavioral Research in Accounting, vol. 14, no. 1, pp. 247271, DOI: http://dx.doi.org/ 10.2308/bria.2002.14.1.247. 
37. Wofford, J.C. and Goodwin, V.L. (1990), Effects of feedback on cognitive processing and choice of decision style, Journal of Applied Psychology, vol. 75 , no. 6, pp. 603-612, DOl: http://dx.doi.org/10.1037/0021-9010.75.6.603.

38. Yilmaz, E., Ozer, G. and Gunluk, M. (2014), Do Organizational Politics and Organizational Commitment Affect Budgetary Slack Creation in Public Organizations? Procedia - Social and Behavioral Sciences, vol. 150, pp. 241-250, DOI: http://dx.doi.org/10.1016/j.sbspro.2014.09.047.
39. Yunos, M.R., Zubaidah, I. and Smith, M. (2012), Ethnicity and accounting conservatism: Malaysian evidence, Asian Review of Accounting, vol. 20, no. 1, pp. 34-57, DOI: http://dx.doi.org/10.1108/13217341211224718.

40. Zeti, A. (2010), Reflection on Small and Medium Sized Enterprises. In BIS Review 98/2010: Keynote address at the $7^{\text {th }}$ Conference of Asia Pacific Economic Cooperation (APEC) Financial Institutions Dealing with SMEs held on 16 July 2010 at Lanai Kijang, Kuala Lumpur. Kuala Lumpur: Lanai Kijang. 